\title{
Variability along a latitudinal gradient in the chiasma frequency and morphological characters of Dichroplus pratensis (Orthoptera: Acrididae)*
}

\author{
Claudio J. BIDAU ${ }^{1,2}$ and DARDo A. MARTí ${ }^{2}$ \\ ${ }^{1}$ Laboratório de Zoologia de Vertebrados, Zoologia - DBAV-B-UERJ (Universidade do Estado do Rio de Janeiro), Rua São \\ Francisco Xavier 524, Maracanã, Rio de Janeiro, RJ, 20550-900 Brazil; e-mail: bidau50@hotmail.com \\ ${ }^{2}$ Laboratorio de Genética Evolutiva, Universidad Nacional de Misiones, Félix de Azara 1552, (3300) Posadas, Misiones, Argentina \\ and Consejo Nacional de Investigaciones Científicas y Tecnológicas, Rivadavia 1917, (1033) Buenos Aires, Argentina
}

Key words. Central-marginal distribution, chiasmata, Dichroplus, latitudinal gradient, morphological variability, recombination, Robertsonian translocation

\begin{abstract}
The grasshopper Dichroplus pratensis Bruner is polymorphic and polytypic for a complex Robertsonian system. In this species, centric fusions induce changes in number and position of chiasmata, and thus potentially affect intrachromosomal genetic recombination and genetic variability. Males and females, from 23 populations covering most of the geographic range of the species and spanning 22 degrees of latitude, were studied. We analyzed chiasma frequency in relation to variability in six exomorphological characters. The chromosomal polymorphisms of $D$. pratensis are widely geographically distributed, and show a central-marginal pattern, in which the central populations (those occupying the ecologically optimal habitats) have high mean frequencies of different fusions per individual $(F)$ of up to $F=3.00$ and total chiasma frequencies as low as $X_{T}=8.98$ per cell, while those near the margins of the distribution (central Patagonia and the Andes) have very low levels of chromosomal polymorphisms [down to $F=0.00$ in most geographically marginal locations), monomorphic karyotypes and high chiasma frequencies $\left(X_{T}=11.66\right.$, in the southernmost (Rada Tilly, $45^{\circ} 57^{\prime} \mathrm{S}$ ) and $X_{T}=12.01$ in the northernmost population (Volcán, 23 $55^{\prime} \mathrm{S}$ )]. Increasing chiasma frequencies towards the margins of the range are positively and significantly correlated with increasing levels of morphological variability. The decrease in fusion polymorphism and the consequent increase in genetic recombination (both inter- and intrachromosomal) in the marginal areas, is a result of natural selection favouring higher levels of variability, which could be adaptive in ecologically harsher and changing environments.
\end{abstract}

\section{INTRODUCTION}

The widespread existence of chromosomal polymorphisms and polytypisms in natural populations of animal and plant species, is interpreted by several authors as a means of controlling genetic recombination (Carson, 1975; Shaw et al., 1986; Bidau, 1993; Korol et al., 1994; Bidau et al., 2001). Genetic recombination is an important component of genetic systems, adaptation and speciation (Otto \& Michalakis, 1998; Rieseberg, 2001; OrtizBarrientos et al., 2002). It is well documented that the vast majority of structural chromosomal rearrangements induce changes in the number and position of chiasmata, thus potentially affecting intrachromosomal genetic recombination (White, 1973, 1978; Bidau, 1993; King, 1993). Some rearrangements such as Robertsonian translocations (centric fusions) also modify interchromosomal recombination by reducing the number of independently assorting linkage groups. Hence, chromosomal rearrangements may have a profound impact on the genetic system and genetic variability of a species (Bidau, 1990, 1993; Bidau \& Martí, 1995; Bidau et al., 2001; Martí \& Bidau, 1995).

A number of chromosomal polymorphisms are known to have particular geographical distributions in which ecologically central or optimal populations tend to be highly chromosomally polymorphic while those at or near the margins of the distribution generally show very low levels of chromosomal polymorphism (Brussard, 1984; Powell, 1997). This Central-Marginal model is particularly well studied in several species of Drosophila with paracentric inversion polymorphisms and several explanations have been proposed since Dobzhansky's and Carson's classical papers (da Cunha \& Dobzhansky, 1954; da Cunha et al., 1959; Carson, 1955, 1956, 1958, 1959; Carson \& Heed, 1964; Soule, 1973; Wallace, 1984). All these hypotheses rely more or less on the strong effects of paracentric inversions on crossing-over and recombination in Drosophila females (Brussard, 1984).

The South American Melanopline grasshopper, Dichroplus pratensis, which is widespread in Argentina, is polymorphic and polytypic for a complex system of eight centric fusions which involve the six large autosomal pairs of the $2 n=19 / 20$ standard all-telocentric karyotype and includes several chromosomal races (Bidau et al., 1991). These translocations have a profound effect on chiasma frequency and localization (Bidau 1990, 1993; Bidau \& Mirol 1988; Bidau \& Martí 1995) and as recently discovered the distribution of the polymorphisms shows a central-marginal variation and there is significant morphological variation within the range of the species (Bidau \& Martí, 2002, 2004a). In this paper, we analyze the relationship between chiasma frequency, localisation

\footnotetext{
* This paper is dedicated to the late Dr. Rogelio Santos Stampella, dear friend and honest scientist.
} 
and morphological variability in populations of $D$. pratensis distributed along a $22^{\circ}$ latitudinal gradient that includes central as well as marginal populations. Central populations are highly polymorphic and display low chiasma frequencies and distal localisation in males and females, while marginal populations are all telocentric or have low frequencies of fusions but high chiasma frequencies in males (Bidau, 1990; Bidau \& Martí, 1995, 2002). Thus, marginal populations should have increased levels of genetic recombination and morphological variability. The correlation between chiasma frequency, an estimate of genetic recombination, and morphological variability was previously analyzed in several organisms (Rees \& Dale, 1974; Price \& Bantock, 1975; Westerman, 1983). In the present case, however, the results do not agree with previous findings.

\section{MATERIAL AND METHODS}

A total of 334 and 275 adult males and females, respectively, of $D$. pratensis, from the 23 Argentine localities shown in Table 1 and Fig. 1, were analyzed (numbers of individuals studied per population can be found in Table 1 of Bidau \& Martí, 2004a). Male karyotypes and number of chiasmata were counted in haematoxylin squashes of testes. Female mitoses were obtained from gut caeca and ovaries after injection of $0.05 \%$ colchicine. Meiosis was studied in the eggs of females that exhibited oviposition behaviour. The eggs were dissected in insect saline and fixed in 3 methanol: 1 glacial acetic acid and kept at $4^{\circ} \mathrm{C}$. The exochorion was removed and the micropilar end of the egg squashed in lacto-propionic orcein (Martí \& Bidau, 1995). Morphological measurements of specimens were made using a micrometer $(0.01 \mathrm{~mm})$. Six morphological characters were measured: Total body length [BL; in order to avoid error resulting from the shrinking of the abdomen in dried specimens, this measurement was taken from the tip of the head to the distal end of the left third femur when aligned parallel to the longitudinal axis of the body, as described in Martí (2002)], length of left femur 3 (F3L), length of left tibia 3 (T3L), length of tegmina (TeL), length of pronotum (PL) and height of pronotum $(\mathrm{PH})$. The variability of each of the 6 morphological characters was evaluated using Coefficient of Variation $(C V)$, which is $s \mathrm{x}$ $100 / \bar{x}$, where $s$ and $\bar{x}$, are the standard deviation and mean of the character, respectively. The $C V$ was preferred to the variance or standard deviation as a measure of variability because character means differ significantly among populations. The $C V$ of characters with very different means are directly comparable, while variances and standard deviations are not. (Sokal \& Rohlf, 1995). Because of allometry all six exomorphological characters are highly correlated. To avoid pseudoreplication in the statistical treatment of the data, Principal Components Analysis (PCA) was employed to analyze the relationship between morphological variability and a series of parameters used to estimate recombination, and the latitude and altitude where the populations were sampled. Three PCAs were performed: one for each sex, using 12 variables including the means of the six measurements and their respective standard deviations $(S D)$ for each population, and a joint analysis of both sexes including 24 variables (the 12 means and their respective $S D$ s). For PCA, the $S D$ was preferred to the $C V$ because the mean is included in the calculation of the latter. Ten metaphase I cells from each individual were scored for chiasmata and the mean chiasma frequency was calculated for each population; the between-cell variance in mean chiasma frequency was used as a measure of variability (Bidau \& Martí, 2002). Also, each population was characterized by its $F$ value, which represents the mean frequency of different fusions per individual (irrespective of the fusion being homozygous or heterozygous; see Bidau, 1990) per population. This variable is useful since it is an estimate of the degree to which interchromosomal recombination is affected by centric fusions. Finally, an ad hoc recombination index $(R I)$ was calculated for each population by adding mean chiasma frequency to the value $10-F$ (where $F$ is the parameter defined above, and 10 is the number of independently-assorting elements in standard individuals). Only male chiasma frequency was considered since females invariably show the lowest possible chiasma frequency, i.e. one chiasma per chromosome arm (Martí \& Bidau, 1995), and between cell variance is extremely low independent of the number of fusions per cell. This $R I$ takes into account the number of pairs of chromosomal configurations independently transmitted during meiosis and assesses both intra and interchromosomal recombination.

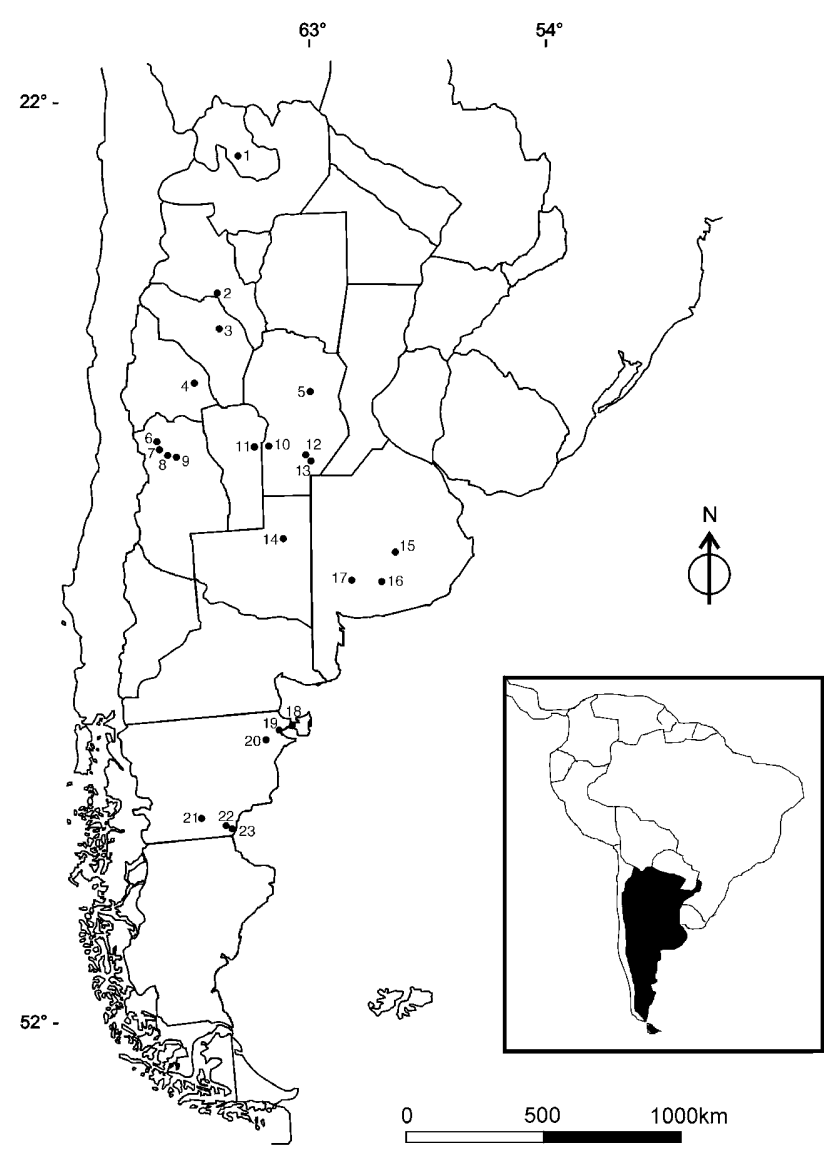

Fig. 1. Geographic distribution of the Argentinian populations of Dichroplus pratensis analyzed in this paper (province, in parentheses). 1 - Volcán (Jujuy); 2 - Estación Mazán (Catamarca); 3 - Carrizal (La Rioja); 4 - Las Juntas (San Juan); 5 Cañada Machado (Córdoba); 6 - Guido (Mendoza); 7 Potrerillos (Mendoza); 8 - Cacheuta (Mendoza); 9 - Compuertas (Mendoza); 10 - Achiras (Córdoba); 11 - Saladillo (San Luis); 12 - La Granja (Córdoba); 13 - Manantiales (Córdoba); 14 - Don Tomás (La Pampa); 15 - Olavarría (Buenos Aires); 16 - Coronel Pringles (Buenos Aires); 17 - Cerro Ceferino (Buenos Aires); 18 - Istmo Ameghino (Chubut); 19 - Puerto Madryn (Chubut); 20 - National Route no. 3, Km 1430 (Chubut); 21 - Lago Musters (Chubut); 22 - Diadema Argentina (Chubut); 23 - Villa Rada Tilly (Chubut). 


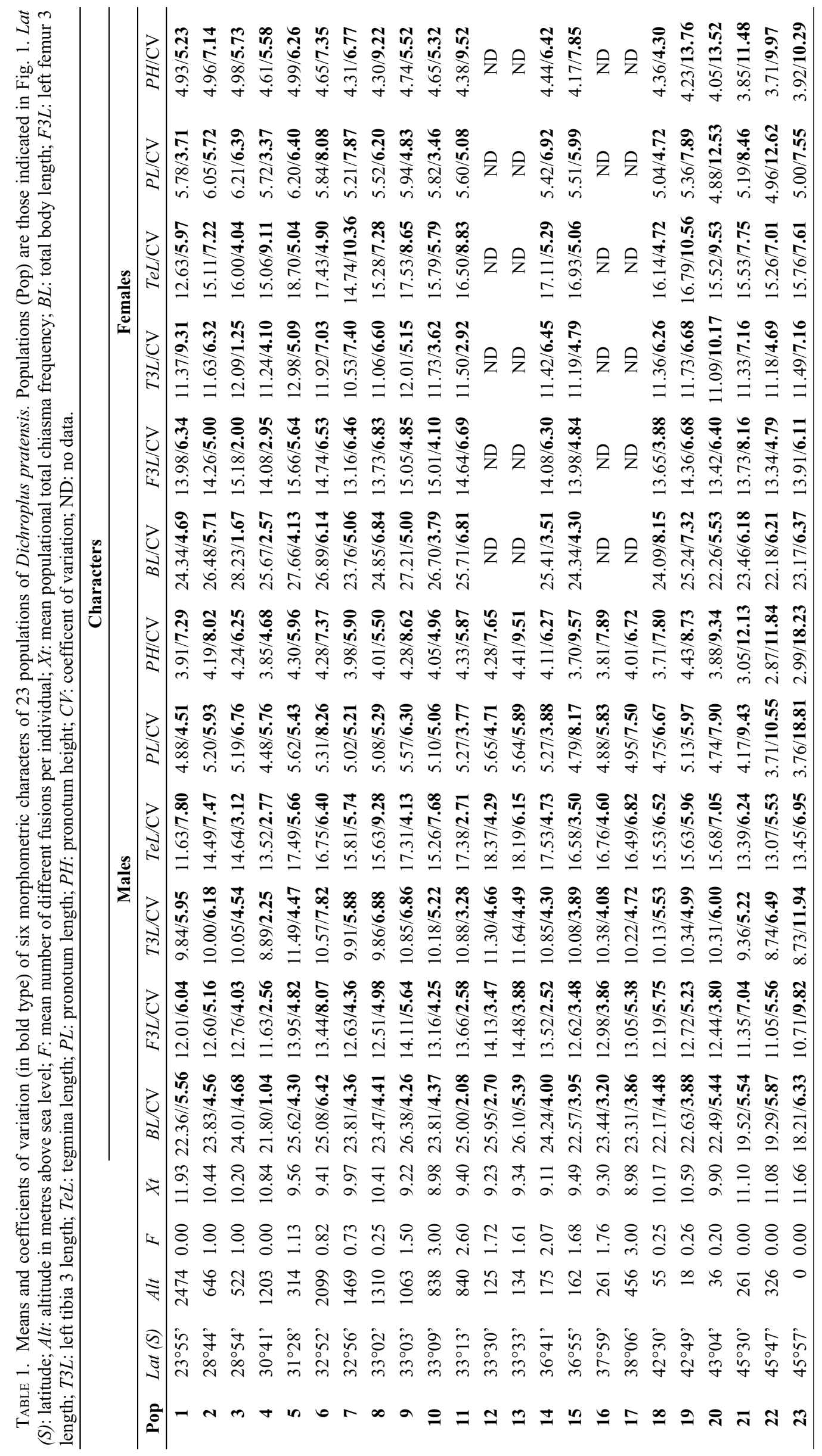




\section{RESULTS AND DISCUSSION}

\section{Variation in chiasma frequency and centric fusions}

The 23 populations analyzed span 22 degrees of latitude and extend from sea level to an altitude of $2474 \mathrm{~m}$ (Fig. 1 and Table 1). Detailed morphological analyses are published elsewhere (Bidau \& Martí, 2004a). These populations include the northernmost locality from which $D$. pratensis is known (Volcán, which incidentally is located at the highest known altitude for the species) as well as three Patagonian localities, which represent the southern margin of the geographical distribution (Villa Rada Tilly, Diadema Argentina and Lago Musters). The populations belong to several different chromosomal races that include centric fusions L1.L2, L1.L4, L1.L6, L2.L5, L3.L4 and L5.L6, as well as a standard (all telocentric) race (Bidau \& Martí, 2002).

The study of meiosis demonstrated that the frequencies of chiasmata and interchromosomal recombination increase with increase in both latitude (towards South) and altitude (towards North and West) (Bidau \& Martí, 2002); both parameters are negatively correlated with a decrease in the frequencies of Robertsonian $(\mathrm{Rb})$ translocations towards the margins of the geographic distribution (Bidau \& Martí, 2002, 2004a). As predicted previously, all the marginal populations turned out to be telocentric and monomorphic with high frequencies of recombination in males (Bidau et al., 1991; Bidau \& Martí, 2002). Also, the existence of two-track heredity was demonstrated, since the females invariably have minimal chiasma frequencies, independent of population and presence or absence of $\mathrm{Rb}$ translocations. Thus, centric fusions affect male meiosis but not the female chiasma frequency, although they dramatically modify chiasma localisation and the amount of interchromosomal recombination in both sexes. The relationship between mean chiasma frequency in each of the 23 populations and mean number of different fusions per individual per population $(F)$ was negative and statistically highly significant (Table 2). Between-cell variance in chiasma frequency also showed a highly significant negative correlation with $F$, which is expected since between-cell variance increases significantly with total chiasma frequency (Table 2) because centric fusions strongly limit the number and position of chiasmata (Bidau, 1990; Bidau \& Martí, 1995, 2002).

TABLE 2. Relationships between the mean number of different fusions per individual per populations $(F)$ and the chiasma characteristics of 23 populations of Dichroplus pratensis. Xt: mean population total chiasma frequency; $S^{2}$ : population between-cell variance in chiasma frequency; $r$ : Pearson's correlation coefficient; $a$ : intercept of the linear regression; $b$ : slope of the linear regression; $d f$ : degrees of freedom; $t: t$-statistic for $r ; p$ : probability.

\begin{tabular}{lrrrrc}
\hline Relationship & $r$ & \multicolumn{1}{c}{$a$} & \multicolumn{1}{c}{$b$} & $d f$ & $p$ \\
\hline$X t / F$ & -0.83 & 10.80 & -0.74 & 21 & $<0.0001^{* * *}$ \\
$S^{2} n / F$ & -0.64 & 1.31 & -0.40 & 21 & $0.0009^{* * *}$ \\
$S^{2} n / X t$ & 0.63 & -3.53 & 0.44 & 21 & $0.0012^{* *}$ \\
\hline
\end{tabular}

\section{Variability in morphological characters}

As previously shown (Bidau \& Martí, 2004a), D. pratensis exhibits ample body size variation both within and between populations along its geographical range. Females are larger than males throughout the range, although the species shows an inversion of Rensch's rule in that sexual size dimorphism (SSD) decreases as mean size increases. Absolute size of males and females is correlated with the central-marginal distribution of chromosomal polymorphisms: body size decreases and SSD increases towards the margins of the distribution (Bidau \& Martí, 2004a). However, variance in all six traits was very different in different populations (Bidau \& Martí, 2004a). On first inspection, large $C V$ s were associated with small morphological measurements in both sexes (Table 1), and $C V$ s for all 6 characters of males and females, were positively correlated (Table 3 ) indicating that populations were more or less morphologically variable as a whole. Although significant differences in mean measurements between males and females occur throughout the range of the species (Table 4) the distribution of $C V \mathrm{~s}$ is essentially similar in both sexes indicating that males and females show the same amount of morphological variability (Table 4).

\section{Morphological variability and estimates of recombination}

Since populations of $D$. pratensis vary not only in mean body size but also in fusion quality and frequencies, and given that fusions have a dramatic effect on intra- and interchromosomal recombination, we tested the hypothesis that populations with low fusion frequencies (i.e. high chiasma frequencies and interchromosomal recombination) should undergo more genetic recombination than those with high fusion frequencies hence releasing more genetic variability which could be reflected in phenotypic (morphological) variability. A Principal Components Analysis (PCA) of the correlation among variables (see Materials and Methods) in males generated three components (Table 5). It can be seen in Table 5 that the six variables corresponding to the means of each character show high loadings on principal component 1 , indicating that this component is related to size. The other six variables (standard deviations) show high loadings mainly on com-

TABLE 3. Correlations between coefficients of variation (CV) of six morphological characters of 23 populations of Dichroplus pratensis. $r$ : Pearson's correlation coefficient; $a$ : intercept of the linear regression line; $b$ : slope of the linear regression line; $d f$ : degrees of freedom; $p$ : probability. (See Materials and Methods and Table 1 for meaning of abreviations.)

\begin{tabular}{lccccl}
\hline Relationship & $r$ & $a$ & $b$ & $d f$ & \multicolumn{1}{c}{$p$} \\
\hline CVBLm/CVBLf & 0.30 & 3.01 & 0.26 & 21 & $0.1572 \mathrm{~ns}$ \\
CVF3Lm/CVF3Lf & 0.32 & 2.67 & 0.41 & 21 & $0.1406 \mathrm{~ns}$ \\
CVT3Lm/CVT3Lf & 0.44 & 2.99 & 0.43 & 21 & $0.0375 *$ \\
CVTeLm/CVTeLf & 0.00 & 3.13 & 0.56 & 21 & $0.9928 \mathrm{~ns}$ \\
CVPLm/CVPLf & 0.42 & 3.30 & 0.58 & 21 & $0.0428^{*}$ \\
CVPHm/CVPHf & 0.50 & 5.68 & 0.00 & 21 & $0.0181^{*}$ \\
\hline
\end{tabular}



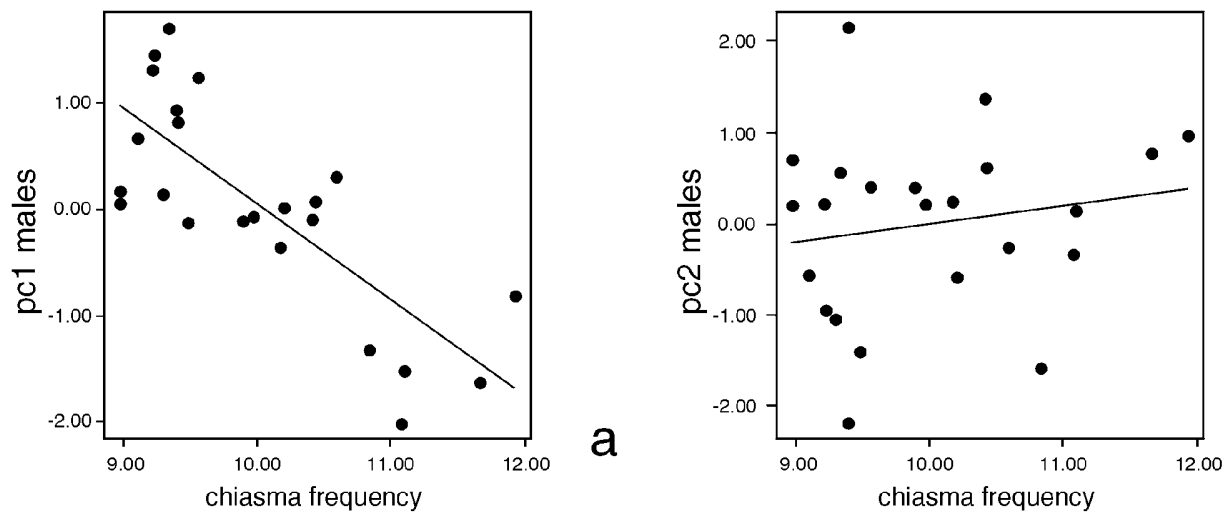

b
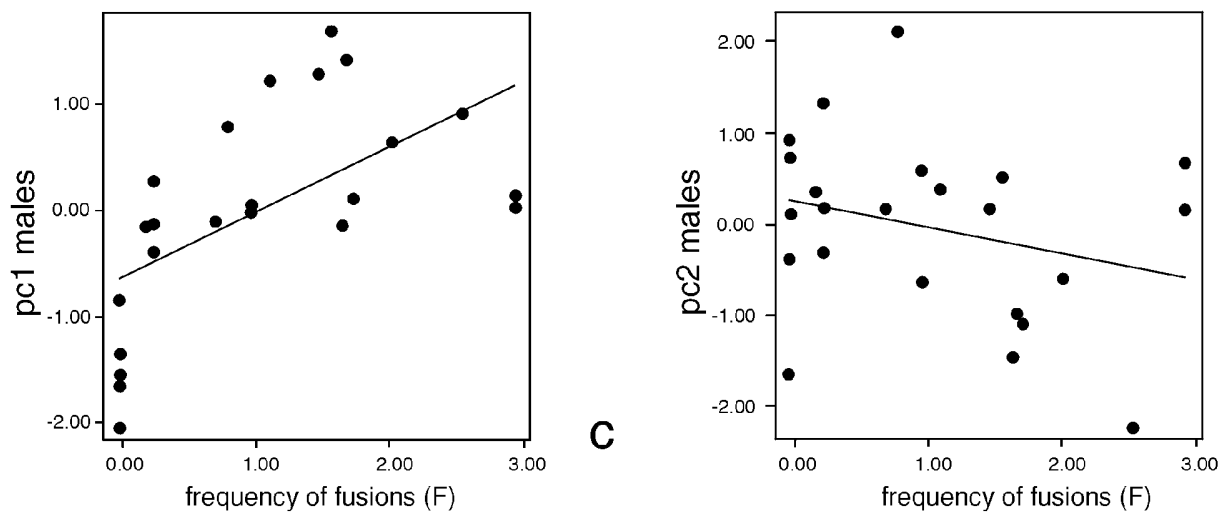

d
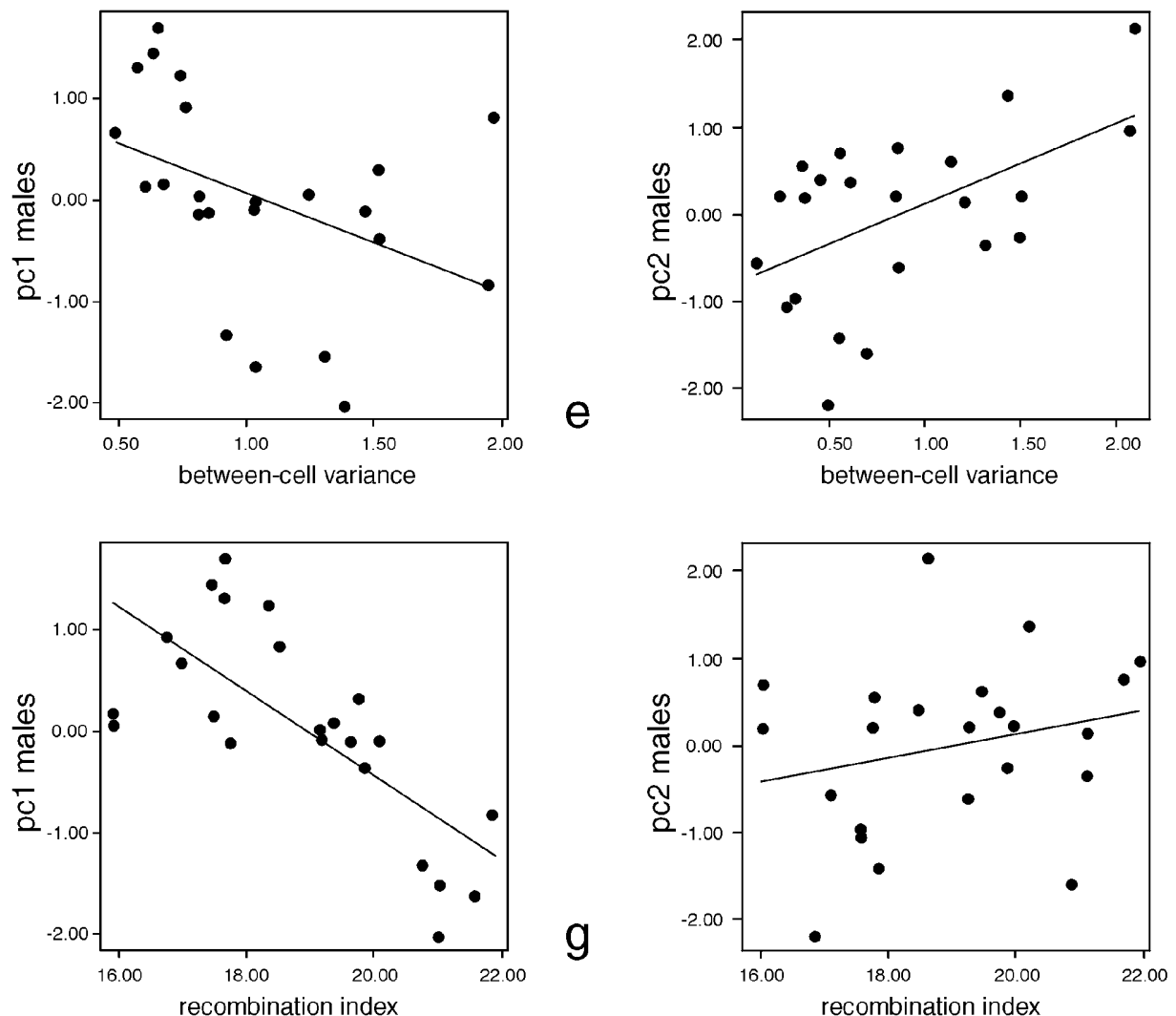

$\mathrm{h}$

Fig. 2. Regression of the first and second principal components (pc1, pc2) obtained from the Principal Component Analysis performed on males of $D$. pratensis, on total cell mean chiasma frequency $(\mathrm{a}, \mathrm{b})$, mean frequency of different fusions per individual (c, $\mathrm{d})$, between-cell variance in total chiasma frequency $(\mathrm{e}, \mathrm{f})$ and recombination index $(\mathrm{g}, \mathrm{h})$. 
Table 4. Results of Student's $t$ test and Wilcoxon Signed Ranks test comparing the mean values of six morphological characters, the coefficients of variation $(\mathrm{CV})$ of the same characters and the distribution of means and $C V \mathrm{~s}$ between males and females of Dichroplus pratensis. (See Materials and Methods and Table 1 for meaning of the abreviations.)

\begin{tabular}{lcccc}
\hline \multirow{2}{*}{ Character } & \multicolumn{2}{c}{ Student's $t$ test } & \multicolumn{2}{c}{ Wilcoxon test } \\
\cline { 2 - 5 } & \multicolumn{1}{c}{$t$} & \multicolumn{1}{c}{$p$} & \multicolumn{1}{c}{$p$} \\
\hline BL & -6.92 & $0.0000^{* * *}$ & -3.70 & $0.0000^{* * *}$ \\
$C V$ BL & -1.84 & $0.0823 \mathrm{~ns}$ & -1.81 & $0.0701 \mathrm{~ns}$ \\
F3L & -10.03 & $0.0000^{* * *}$ & -3.82 & $0.0000^{* * *}$ \\
$C V$ F3L & -1.01 & $0.3254 \mathrm{~ns}$ & -1.05 & $0.2956 \mathrm{~ns}$ \\
T3L & -10.15 & $0.0000^{* * *}$ & -3.82 & $0.0000^{* * *}$ \\
$C V$ T3L & -0.46 & $0.6517 \mathrm{~ns}$ & -0.68 & $0.4940 \mathrm{~ns}$ \\
TeL & -3.02 & $0.0074^{* *}$ & -2.56 & $0.0110^{*}$ \\
$C V$ TeL & -2.24 & $0.0379^{*}$ & -1.69 & $0.0910 \mathrm{~ns}$ \\
PL & -7.22 & $0.0000^{* * *}$ & -3.82 & $0.0000^{* * *}$ \\
$C V$ PL & 0.41 & $0.6859 \mathrm{~ns}$ & -0.02 & $0.9840 \mathrm{~ns}$ \\
PH & -7.24 & $0.0000^{* * *}$ & -3.70 & $<0.0001^{* * *}$ \\
$C V$ PH & 0.23 & $0.8184 \mathrm{~ns}$ & -0.16 & $0.8721 \mathrm{~ns}$ \\
\hline
\end{tabular}

ponent 2, thus, this component is related to morphological variability. Component 1 was linearly regressed on the four variables used to estimate recombination, which revealed significant negative relationships with chiasma frequency, cell variance and recombination index, while the relationship with $F$ was positive and significant as expected (Table 7; Fig. 2). An opposite result was obtained when factor 2 was used as the dependent variable in the same comparisons, indicating that morphological variability tends to increase with recombination. The parallel analysis for females (Table 5) was less revealing but not contradictory. Again, high loadings for the variables representing means were obtained on component 1 while components 2 and 3 shared high loadings for the variance variables (Table 7). Slopes of regression lines tend to parallel those for males. Thus, the "size" component is negatively correlated with high levels of recombination, while the "variability" component $(s)$ is positively correlated. The first is not surprising, since higher levels of recombination occur in marginal populations where body sizes are significantly smaller than in central populations (Bidau \& Martí, 2004a). However, the fact that the variability in morphological characters tends to increase with recombination suggests a causal relationship between morphological variability and increased levels of genetic recombination (see below). Similar results were obtained when both sexes were analysed jointly by means of PCA (Tables 6, 7). In general, principal components associated with size tended to be negatively correlated with levels of recombination (and positively with increase in fusion frequency), while components associated with variability tended to show the opposite trend.

\section{Morphological variability, latitude and altitude}

The decrease in body size of $D$. pratensis at high latitudes and altitudes indicates these grasshoppers show the
TABLE 5. Principal Components Analysis of morphological data of populations of Dichroplus pratensis studied in this paper. Three factors for each sex were extracted and rotated with the VARIMAX procedure with Kaiser Normalization for 12 variables. (See Materials and Methods and Table 1 for meaning of the abreviations). Values correspond to correlation coefficients between variables and factors. Relatively high loadings $(|r|>0.5)$ are marked with an asterisk.

\begin{tabular}{lcccccc}
\hline & \multicolumn{3}{c}{ Males } & \multicolumn{3}{c}{ Females } \\
\cline { 2 - 7 } & \multicolumn{1}{c}{ Principal Component } & \multicolumn{3}{c}{ Principal Component } \\
\hline BL & $0.955^{*}$ & 0.005 & -0.185 & $0.855^{*}$ & -0.395 & -0.217 \\
F3L & $0.982^{*}$ & -0.048 & -0.093 & $0.944^{*}$ & -0.209 & -0.149 \\
T3L & $0.963^{*}$ & -0.016 & -0.028 & $0.918^{*}$ & -0.071 & -0.037 \\
TeL & $0.887^{*}$ & -0.176 & 0.121 & $0.755^{*}$ & 0.406 & -0.038 \\
PL & $0.949^{*}$ & 0.045 & -0.240 & $0.751^{*}$ & -0.534 & -0.193 \\
PH & $0.869^{*}$ & 0.0004 & -0.288 & $0.594^{*}$ & $-0.718^{*}$ & -0.110 \\
SBL & -0.110 & $0.803^{*}$ & 0.138 & -0.071 & 0.187 & $0.720^{*}$ \\
SF3L & -0.149 & $0.747^{*}$ & 0.507 & 0.018 & 0.242 & $0.864^{*}$ \\
ST3L & -0.066 & $0.737^{*}$ & 0.542 & -0.359 & -0.009 & $0.757^{*}$ \\
STeL & 0.150 & $0.803^{*}$ & -0.130 & -0.076 & 0.466 & 0.376 \\
SPL & -0.366 & 0.322 & $0.771 *$ & -0.092 & $0.790^{*}$ & 0.074 \\
SPH & -0.036 & 0.058 & $0.933^{*}$ & -0.030 & $0.716^{*}$ & 0.470 \\
\hline \% Variance & 45.365 & 21.109 & 18.747 & 34.166 & 21.811 & 19.403 \\
explained & & & & & & \\
\hline
\end{tabular}

converse to Bergmann's rule (Bidau \& Martí, 2004a). However, inversion of Bergmann's rule does not imply that morphological variability increases with decrease in body size. Nevertheless, that is the case in this species (Table 1): marginal populations show the highest $C V \mathrm{~s}$ for all morphological measurements. Marginal populations of $D$. pratensis occupy ecologically suboptimal environments in Patagonia in the South, and the sub-Andean localities at more than $1000 \mathrm{~m}$ above seal level in the West and North. These populations have the lowest $F$ values and highest chiasma frequencies and between-cell variances. Indeed, when the principal components were plotted against latitude (Table 8), in all cases the regression lines were quadratic, not linear. This is because both the size and variability components show opposite clines in high and low latitudes. Thus, while body size decreases at the higher latitudes (towards the south) and altitudes (towards the north), morphological variability for these characters tends to follow the opposite trend (Figs 3, 4). This effect is more pronounced in males than in females. The same phenomenon, although somewhat attenatued, was observed for altitude (Table 8).

Thus as predicted, marginal populations have increased levels of genetic recombination and morphological variability. The observed patterns of latitudinal distribution in morphological variability (related to changes in recombination) are more marked in males than females. This is obviously not related to recombination but probably to growth constraints that operate differentially in both sexes. D. pratensis is sexually size dimorphic with females larger than males (Bidau \& Martí, 2004a). However, females are less variable in size since sexual size dimorphism (SSD) follows the converse of Rensch's rule, 

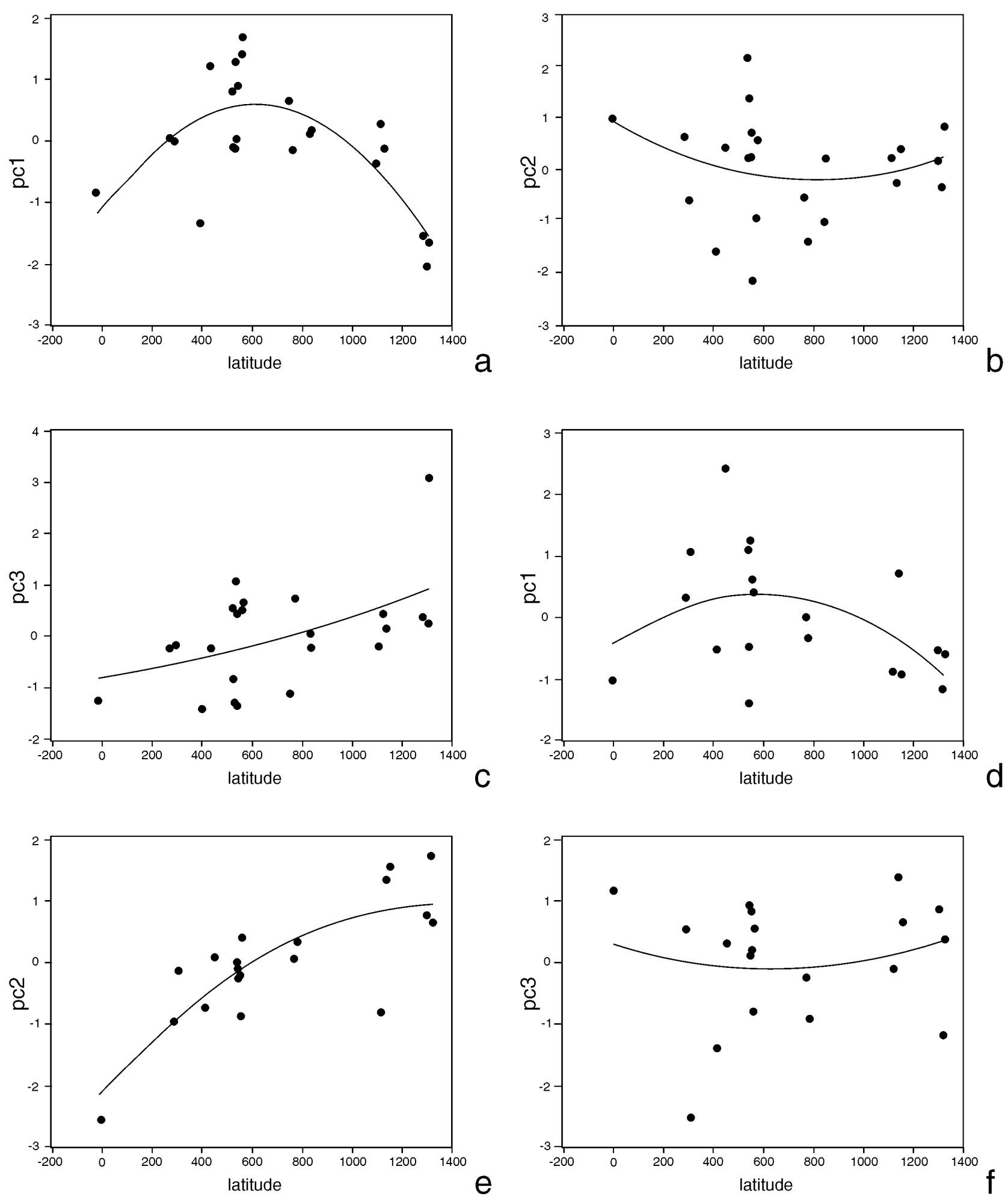

Fig. 3. Regression (quadratic) of the three principal components (pc1, pc2, and pc3) obtained from the Principal Component Analyses performed on males and females of D. pratensis, on latitude (in minutes). a, b, c-males; d, e, f-females.

that is, SSD decreases as mean body size increases (Fairbairn, 1997). For example, in the populations analysed in this paper, the difference in mean body size between the population with the largest females and that with the smallest is $6.05 \mathrm{~mm}$, while the same difference for males is $8.17 \mathrm{~mm}$. Females are also less variable at the intra- populational level and this is probably related to selection favouring early male emergence, which is correlated with duration of development and the extension of the adult season (shorter in marginal populations) (Morbey \& Ydenberg, 2001; Bidau \& Martí, 2004a). Early emergence of males implies protandry and intense competition 
TABLE 6. Joint Principal Components Analysis of morphological data of males and females from the populations of Dichroplus pratensis studied in this paper. Six factors were extracted and rotated with the VARIMAX procedure with Kaiser Normalization for 24 variables. (See Materials and Methods and Table 1 for meaning of the abreviations.) Values correspond to correlation coefficients between variables and factors. Relatively high loadings $(|r|>0.5)$ are marked with an asterisk; $\mathrm{m}-$ male; $\mathrm{f}-\mathrm{females}$.

\begin{tabular}{|c|c|c|c|c|c|c|}
\hline \multirow{2}{*}{ Variable } & \multicolumn{6}{|c|}{ Principal Component } \\
\hline & 1 & 2 & 3 & 4 & 5 & 6 \\
\hline BLm & $0.697 *$ & $0.567 *$ & -0.318 & 0.106 & -0.035 & -0.108 \\
\hline F3Lm & $0.614^{*}$ & $0.710 *$ & -0.277 & 0.075 & 0.027 & -0.060 \\
\hline T3Lm & $0.533^{*}$ & $0.743 *$ & -0.232 & 0.186 & 0.080 & -0.008 \\
\hline TeLm & 0.202 & $0.942 *$ & -0.137 & 0.002 & 0.097 & -0.034 \\
\hline PLm & $0.734 *$ & $0.520 *$ & -0.351 & 0.172 & 0.021 & -0.120 \\
\hline PHm & $0.747 *$ & 0.387 & -0.387 & 0.093 & 0.165 & -0.143 \\
\hline BLf & $0.888^{*}$ & 0.269 & -0.012 & -0.213 & -0.200 & -0.083 \\
\hline F3Lf & $0.844^{*}$ & 0.327 & 0.206 & -0.261 & -0.101 & 0.009 \\
\hline T3Lf & $0.732 *$ & 0.321 & 0.376 & -0.146 & -0.108 & 0.162 \\
\hline TeLf & 0.233 & $0.853 *$ & 0.287 & -0.202 & 0.031 & 0.151 \\
\hline PLf & $0.925^{*}$ & 0.040 & -0.080 & -0.167 & -0.219 & -0.030 \\
\hline PHf & $0.896^{*}$ & -0.015 & -0.217 & 0.021 & -0.300 & -0.123 \\
\hline SBLm & 0.126 & -0.222 & 0.399 & $0.568^{*}$ & -0.331 & $0.516^{*}$ \\
\hline SF3Lm & 0.108 & -0.094 & $0.807^{*}$ & $0.514^{*}$ & -0.092 & -0.001 \\
\hline ST3Lm & -0.032 & -0.014 & $0.689 *$ & $0.593 *$ & -0.048 & 0.034 \\
\hline STeLm & -0.031 & 0.082 & 0.065 & $0.847^{*}$ & -0.066 & -0.015 \\
\hline SPLm & -0.175 & -0.199 & 0.881 & -0.013 & 0.026 & 0.150 \\
\hline SPHm & -0.247 & 0.042 & 0.772 & 0.008 & 0.427 & 0.042 \\
\hline SBLf & -0.253 & 0.242 & 0.351 & 0.487 & 0.350 & -0.450 \\
\hline SF3Lf & -0.103 & 0.200 & 0.088 & $0.594^{*}$ & $0.535^{*}$ & 0.015 \\
\hline ST3Lf & -0.201 & -0.165 & 0.032 & $0.824^{*}$ & 0.228 & 0.148 \\
\hline STeLf & -0.127 & 0.039 & -0.047 & -0.027 & $0.850^{*}$ & -0.116 \\
\hline SPLf & -0.352 & 0.151 & 0.188 & 0.154 & 0.266 & $0.785^{*}$ \\
\hline SPHf & -0.197 & 0.015 & 0.152 & 0.131 & $0.839^{*}$ & 0.327 \\
\hline $\begin{array}{l}\text { \% Variance } \\
\text { explained }\end{array}$ & 26.877 & 16.474 & 15.404 & 13.589 & 10.466 & 5.739 \\
\hline
\end{tabular}

for mates which could explain the higher variability in body size in males. Balancing selection could maintain this variability because although small males may mate earlier, large males could be fitter in other respects, such as fertility. In contrast, females have a longer period of development and selection probably favours bigger body size, which, in insects is usually correlated with fecundity (Andersson, 1994).

One of the hypotheses proposed to explain the decrease in chromosomal polymorphism at the margins of the distribution of several Drosophila species is that chromosomal rearrangements (paracentric inversions in their case) effectively inhibit intrachromosomal recombination in heterozygotes. Marginal populations would benefit from low levels of chromosomal polymorphism and higher recombination that disrupt supergenes and increase genetic variability (and thus morphological variability) (Carson, 1956, 1958; Carson \& Heed, 1964; Brussard, 1984; Powell, 1997). This may also apply to D. pratensis: in this species Robertsonian rearrangements inhibit crossing-over in the pericentromeric regions of fusion chromosomes in heterozygotes and homozygotes and allow the formation of supergenes, which could be adaptive in the different central environments (Chiappero et al., 2004). Furthermore, they also decrease interchromosomal recombination and may create linkage disequilibria. Thus, the absence of fusions in marginal areas implies higher levels of genetic recombination, which could explain the observed increase in morphological variability.

An alternative hypothesis is that variability in marginal populations should be lower than in the centre, since high chiasma frequencies lead to greater release of variability, some of which would then be eliminated by natural selection, while populations with less recombination would tend to retain their variability. This was Westerman's (1983) interpretation of his data on the grasshopper Phaulacridium vittatum. This species is polymorphic for a B chromosome which increases chiasma frequency and between-cell variance. The distribution of the polymorphic B is central-marginal but in this case, marginal populations are more polymorphic (i.e. have higher $B$ frequencies) than those in the centre ones and thus, have higher mean chiasma frequencies. As morphological vari- 

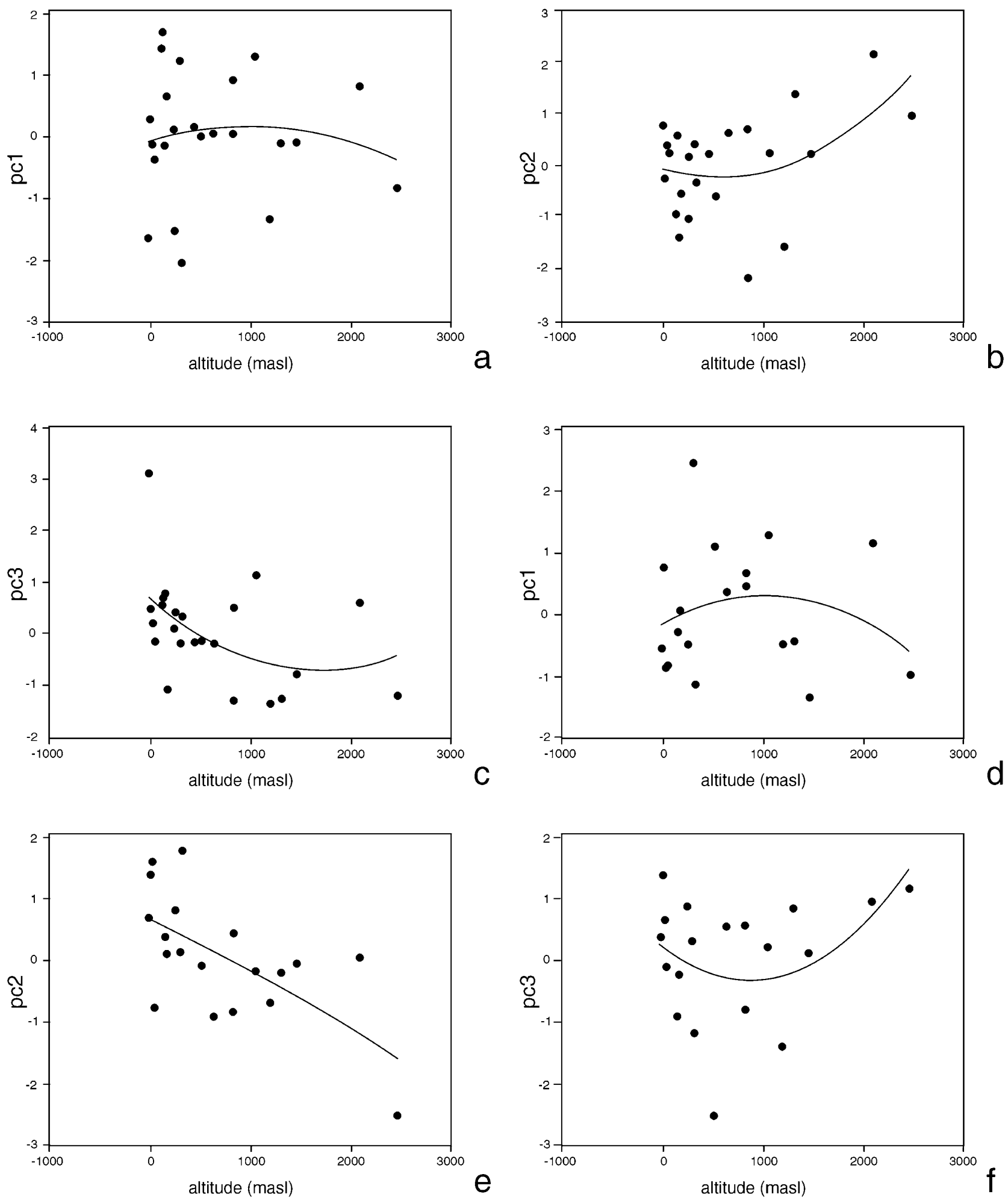

Fig. 4. Regression (quadratic) of the three principal components (pc1, pc2, and pc3) obtained from the Principal Component Analyses performed on males and females of $D$. pratensis, on altitude (metres above sea level). a, b, c-males; d, e, f-females .

ability is inversely correlated with chiasma frequency in this species, Westerman (1983) proposed that most of the genetic and morphological variability released by the higher rates of recombination is rapidly lost through natural selection in marginal populations. The case we report is clearly opposite to this and it can be hypothe- sised that in D. pratensis, natural selection favours the maintenance (and not the elimination) of variability, that is balancing and not directional selection is probably operating (see above). In central populations, recombination and variability would have been high in the early stage of colonisation. Natural selection would have 
TABLE 7. Correlations between principal components ( $\mathrm{pc} 1, \mathrm{pc} 2$, and $\mathrm{pc} 3$ ) and four recombination estimates in Dichroplus pratensis. $S_{X t}^{2}$, between cell variance in total cell mean chiasma frequency; $X t$, total cell mean chiasma frequency per population; $F$, mean number of different fusions per individual; $R I$, recombination index. In the case of the joint male-female analysis, only the first three principal components were considered.

\begin{tabular}{lccccccccc}
\hline \multirow{2}{*}{ Relationship } & \multicolumn{4}{c}{ Males } & \multicolumn{3}{c}{ Females } & \multicolumn{3}{c}{ Males + Females } \\
\cline { 2 - 10 } & $d f$ & $r$ & $p$ & $d f$ & $r$ & $p$ & $d f$ & $r$ & $p$ \\
\hline $\mathrm{pc} 1 / S_{X t}^{2}$ & 21 & -0.42 & $0.0490 *$ & 17 & -0.25 & $0.3002 \mathrm{~ns}$ & 17 & -0.02 & $0.9503 \mathrm{~ns}$ \\
$\mathrm{pc} 2 / S_{X t}^{2}$ & 21 & 0.53 & $0.0088 * *$ & 17 & -0.23 & $0.3434 \mathrm{~ns}$ & 17 & -0.43 & $0.0634 \mathrm{~ns}$ \\
$\mathrm{pc} 3 / S_{X t}^{2}$ & 21 & -0.10 & $0.6431 \mathrm{~ns}$ & 17 & 0.39 & $0.0995 \mathrm{~ns}$ & 17 & 0.20 & $0.4207 \mathrm{~ns}$ \\
$\mathrm{pc} 1 / X t$ & 21 & -0.78 & $0.0000 * * *$ & 17 & -0.52 & $0.0234 *$ & 17 & -0.24 & $0.3141 \mathrm{~ns}$ \\
$\mathrm{pc} 2 / X t$ & 21 & 0.17 & $0.4352 \mathrm{~ns}$ & 17 & -0.09 & $0.7270 \mathrm{~ns}$ & 17 & -0.83 & $0.0000 * * *$ \\
$\mathrm{pc} 3 / X t$ & 21 & 0.10 & $0.6617 \mathrm{~ns}$ & 17 & 0.15 & $0.5320 \mathrm{~ns}$ & 17 & -0.27 & $0.2618 \mathrm{~ns}$ \\
$\mathrm{pc} 1 / F$ & 21 & 0.60 & $0.0027 * *$ & 17 & 0.47 & $0.0447 *$ & 17 & 0.31 & $0.1980 \mathrm{~ns}$ \\
$\mathrm{pc} 2 / F$ & 21 & -0.28 & $0.2025 \mathrm{~ns}$ & 17 & -0.13 & $0.6016 \mathrm{~ns}$ & 17 & 0.56 & $0.0123 *$ \\
$\mathrm{pc} 3 / F$ & 21 & -0.10 & $0.7550 \mathrm{~ns}$ & 17 & -0.21 & $0.3937 \mathrm{~ns}$ & 17 & 0.23 & $0.3358 \mathrm{~ns}$ \\
$\mathrm{pc} 1 / R I$ & 21 & -0.72 & $0.0001 * * *$ & 17 & -0.53 & $0.0192 *$ & 17 & -0.30 & $0.2098 \mathrm{~ns}$ \\
$\mathrm{pc} 2 / R I$ & 21 & 0.24 & $0.2655 \mathrm{~ns}$ & 17 & 0.01 & $0.9840 \mathrm{~ns}$ & 17 & -0.73 & $0.0004 * * *$ \\
$\mathrm{pc} 3 / R I$ & 21 & 0.10 & $0.6633 \mathrm{~ns}$ & 17 & 0.17 & $0.4857 \mathrm{~ns}$ & 17 & -0.26 & $0.2773 \mathrm{~ns}$ \\
\hline
\end{tabular}

TABLE 8. Correlation coefficients (quadratic regression) between principal components and latitude (Lat) and altitude (Alt) in males and females of Dichroplus pratensis. In the case of the joint male-female analysis, only the first three principal components were considered.

\begin{tabular}{|c|c|c|c|c|c|c|c|c|c|}
\hline \multirow{2}{*}{ Relationship } & \multicolumn{3}{|c|}{ Males } & \multicolumn{3}{|c|}{ Females } & \multicolumn{3}{|c|}{ Males + Females } \\
\hline & $d f$ & $r$ & $p$ & $d f$ & $r$ & $p$ & $d f$ & $r$ & $p$ \\
\hline $\mathrm{pc} 1 / \mathrm{Lat}^{\mathrm{a}}$ & 21 & 0.76 & $0.0002 * * *$ & 17 & 0.49 & $0.1146 \mathrm{~ns}$ & 17 & $0.75^{\mathrm{c}}$ & $0.0002 * * *$ \\
\hline $\mathrm{pc} 2 / \mathrm{Lat}^{\mathrm{a}}$ & 21 & 0.25 & $0.5122 \mathrm{~ns}$ & 17 & 0.81 & $0.0002 * * *$ & 17 & 0.81 & $0.0002 * *$ \\
\hline $\mathrm{pc} 3 / \mathrm{Lat}^{\mathrm{a}}$ & 21 & 0.51 & $0.0500^{*}$ & 17 & 0.18 & $0.7589 \mathrm{~ns}$ & 17 & 0.49 & $0.1162 \mathrm{~ns}$ \\
\hline $\mathrm{pc} 1 / \mathrm{Alt}^{\mathrm{b}}$ & 21 & 0.12 & $0.8634 \mathrm{~ns}$ & 17 & 0.25 & $0.5093 \mathrm{~ns}$ & 17 & $0.40^{\mathrm{c}}$ & $0.0875 \mathrm{~ns}$ \\
\hline $\mathrm{pc} 2 / \mathrm{Alt}^{\mathrm{b}}$ & 21 & 0.47 & $0.0875 \mathrm{~ns}$ & 17 & 0.64 & $0.0143^{*}$ & 17 & 0.39 & $0.2625 \mathrm{~ns}$ \\
\hline $\mathrm{pc} 3 / \mathrm{Alt}^{\mathrm{b}}$ & 21 & 0.49 & $0.0680 \mathrm{~ns}$ & 17 & 0.44 & $0.1725 \mathrm{~ns}$ & 17 & 0.32 & $0.4122 \mathrm{~ns}$ \\
\hline
\end{tabular}

${ }^{a}$ Latitude in minutes; ${ }^{\mathrm{b}}$ Altitude in metres above sea level; ${ }^{\mathrm{c}}$ These correlation coefficients correpond to linear regression.

favoured individuals with those genetic combinations most adaptive in the stable conditions of the optimum habitat (thus reducing variability), which could then be preserved by newly arisen $\mathrm{Rb}$ fusions and their effects on recombination, also favoured by selection. In contrast, in marginal populations where the environment is harsher and constantly changing, genotypes that produce variable progeny through genetic recombination, would have been more successful because this increases the probability of survival of at least some of their offspring. This is not to say that selection would act directly on, for example, chiasma frequency because selection acts at the individual phenotypic level and high or low recombination has no fitness consequence for the individuals. However, if high recombination is linked to other phenotypic traits of high fitness value, the character could persist, and factors such as fusions, that inhibit recombination would not be favoured in the difficult conditions of marginal populations. Furthermore, genetic variability would not necessarily be lost through time if the environment changes constantly (for example, on a generation basis) so that different genotypes are adaptive at different times. Thus, some kind of balancing selection could become established. It is worth noting that the frequency of rare B chromosomes which increase chiasma frequency in the carrier cells, is higher in marginal populations of $D$. pratensis than in the central ones, where they are almost absent (Bidau \& Martí, 2002; Bidau et al., 2004), which reinforces the previous hypothesis. One of these B chromosomes, a mitotically unstable one, significantly increases mean chiasma frequency of males and its effect is more marked in standard individuals, which are the majority in marginal populations (Bidau, 1987). Overrepresentation of these $\mathrm{Bs}$ in marginal habitats may be due to selection favouring higher recombination levels or, a consequence of centromeric drive towards acrocentric chromosomes. Although the latter hypothesis is appealing (Bidau \& Martí, 2004b) the former needs to be tested.

ACKNOWLEDGEMENTS. We are extremely grateful to J.P.M. Camacho (Granada, Spain) and two anonymous reviewers for useful suggestions that substantially improved the manuscript. We also thank F. Perfectti (Granada, Spain) for useful hints regarding statistical analyses. Collection of specimens in Patagonia was greatly facilitated by K. Crespo (CEN- 
PAT, Puerto Madryn, Argentina), A.L. Zamit and C.F. Argüelles and their respective families. This work was partially financed by grant PID 0022 CONICET (Argentina) and was completed during CJB's sabbatical leave at the Departamento de Zoologia, Universidade do Estado do Rio de Janeiro, financed by the Fundação de Amparo a Pesquisa do Estado do Rio de Janeiro (FAPERJ), Brazil. This paper would not have been possible without the support and endless love of Rocio (CJB).

\section{REFERENCES}

Andersson M. 1994: Sexual Selection. Princeton University Press, New Jersey, 624 pp.

BIDAU C.J. 1987: Influence of a rare unstable B-chromosome on chiasma frequency and nonhaploid sperm production in Dichroplus pratensis (Melanoplinae, Acrididae). Genetica 73: 201-210.

BIDAU C.J. 1990: The complex Robertsonian system of Dichroplus pratensis (Melanoplinae, Acrididae). II. Effects of the fusion polymorphisms on chiasma frequency and distribution. Heredity 64: 145-159.

BIDAU C.J. 1993: Causes of chiasma repatterning due to centric fusions. Braz. J. Genet. 16: 283-296.

Bidau C.J. \& Martí D.A. 1995: Male and female meiosis in Robertsonian heterozygotes of Dichroplus pratensis (Acrididae). In Brandham P.E. \& Bennett M.D. (eds): Kew Chromosome Conference IV. Royal Botanic Gardens, Kew, UK, pp. 381-396.

BiDAU C.J. \& MARTí D.A. 2002: Geographic distribution of Robertsonian fusions in Dichroplus pratensis (Melanoplinae, Acrididae): the central-marginal hypothesis reanalysed. Cytogenet. Genome Res. 96: 66-74.

BIDAU C.J. \& MARTí D.A. 2004a: Clinal variation of body size in Dichroplus pratensis (Orthoptera: Acrididae): inversion of Bergmann's and Rensch's Rules. Ann. Entomol. Soc. Am. 97: (in press).

BidAu C.J. \& Martí D.A. 2004b: B chromosomes and Robertsonian fusions of Dichroplus pratensis (Acrididae): intraspecific support for the centromeric drive theory. Cytogenet. Genome Res. 106: 347-350.

BidAu C.J. \& Mirol P.M. 1988: Orientation and segregation of Robertsonian trivalents in Dichroplus pratensis (Acrididae). Genome 30: 947-955.

Bidau C.J., Belinco C., Mirol P.M. \& Tosto D.S. 1991: The complex Robertsonian system of Dichroplus pratensis (Melanoplinae, Acrididae). I. Geographic distribution of fusion polymorphisms. Genet. Sel. Evol. 23: 353-370.

Bidau C.J., Giménez M.D., Palmer C.L. \& Searle J.B. 2001: The effects of Robertsonian fusions on chiasma frequency and distribution in the house mouse (Mus musculus domesticus) from a hybrid zone in northern Scotland. Heredity 87: 305-313.

Bidau C.J., Rosato M. \& Martí D.A. 2004: FISH detection of ribosomal cistrons and assortment-distortion for $\mathrm{X}$ and $\mathrm{B}$ chromosomes in Dichroplus pratensis (Acrididae). Cytogenet. Genome Res. 106: 295-301.

BRUSSARD P.F. 1984: Geographic patterns and environmental gradients: the central-marginal model in Drosophila revisited. Annu. Rev. Ecol. Syst. 15: 25-64.

CARSON H.L. 1955: The genetic chracateristics of marginal populations of Drososphila. Cold Spring Harbor Symp. Quant. Biol. 20: 276-287.

CARSON H.L. 1956: Marginal homozygosity for gene arrangement in Drosophila robusta. Science 123: 630-631.
CARSON H.L. 1958: Response to selection under different conditions of recombination in Drosophila. Cold Spring Harbor Symp. Quant. Biol. 23: 291-305.

CARSON H.L. 1959: Genetic conditions which promote or retard the formation of species. Cold Spring Harbor Symp. Quant. Biol. 24: 87-105.

CARson H.L. 1975: The genetics of speciation at the diploid level. Am. Nat. 109: 83-92.

Carson H.L. \& HeEd W.B. 1964: Structural homozygosity in marginal populations of neartic and neotropical species of Drosophila in Florida. Proc. Nat. Acad. Sci. USA 52: 427-430.

Chiappero M., Parise C., Marti D.A, Gardenal C.N. \& Bidau C.J. 2004: Distribution of allozymic genetic variability in populations from two chromosomal races and their hybrid of zone of Dichroplus pratensis (Melanoplinae, Acrididae). $J$. Evol. Biol 17: 76-82.

Da Cunha A.B. \& Dobzhansky T. 1954: A further study of chromosomal polymorphism in Drosophila willistoni in relation to environment. Evolution 8: 119-134.

da Cunha A.B., Dobzhansky, T., Pavlovsky O. \& Spassky B. 1959: Genetics of natural populations. XXVIII. Supplementary data on the chromosomal polymorphism in Drosophila willistoni in relation to the environment. Evolution 13: 389-404.

FAIRBAIRN D.J. 1997: Allometry for sexual size dimorphism: Patterns and processes in the coevolution of body size in males and females. Ann. Rev. Ecol. Syst. 28: 659-687.

KInG M. 1993: Species Evolution. The Role of Chromosome Change. Cambridge University Press, Cambridge, UK, 335 pp.

Korol A.B, Preygel I.A. \& Preygel S.I. 1994: Recombination, Variability and Evolution: Algorithms of Estimation and Population Genetic Models. Chapman \& Hall, London, 376 pp.

MARTí D.A. 2002: Estudios sobre la Meiosis Masculina y Femenina en Especies Argentinas de Acrididos (Melanoplinae). PhD Thesis, Universidad Nacional de Còrdoba, Argentina, $262 \mathrm{pp}$.

Martí D.A. \& Bidau C.J. 1995: Male and female meiosis in a natural population of Dichroplus pratensis (Acrididae) polymorphic for Robertsonian translocations: a study of chiasma frequency and distribution. Hereditas 123: 227-235.

Morbey Y.E. \& Ydenberg R.C. 2001: Protandrous arrival timing to breeding areas: a review. Ecol. Lett. 4: 663-673.

Ortíz-Barrientos D., Reiland J., Hey J. \& Noor M.A.F. 2002: Recombination and the divergence of hybridizing species. Genetica 116: 167-178.

Oтto S.P. \& Michalakis Y. 1998: The evolution of recombination in changing environments. Trends Ecol. Evol. 13: 145-150.

Powell J.P. 1997: Progress and Prospects in Evolutionary Biology: The Drosophila Model. Oxford University Press, New York, Oxford, $576 \mathrm{pp}$.

Price D.J. \& Bantock C.R. 1975: Marginal populations of Cepaea nemoralis (L) on the Brendon Hills, England. II. Variation in chiasma frequency. Evolution 29: 278-286.

Rees H. \& Dale P.J. 1974: Chiasmata and variability in Lolium and Festuca populations. Chromosoma 47: 335-351.

RIESEBERG L.H. 2001: Chromosomal rearrangements and speciation. Trends Ecol. Evol. 16: 351-358.

Shaw D.D., Coates D.J. \& Wilkinson P. 1986. Estimating the genic and chromosomal components of reproductive isolation within and between subspecies of the grasshopper Caledia captiva. Can. J. Genet. Cytol. 28: 686-695. 
SoKal R.R. \& RohlF F.J. 1995. Biometry. 3rd ed. W.H. Freeman, San Francisco, 887 pp.

Soule M. 1973: The epistasis cycle: a theory of marginal populations. Annu. Rev. Ecol. Syst. 4: 165-187.

Wallace B. 1984: A possible explanation for observed differences in the geographic distribution of chromosomal arrangements of plants and Drosophila. Egypt. J. Genet. Cytol. 13: $121-136$.
Westerman M. 1983: Chiasma frequency and variability of morphological characters in populations of two grasshopper species. Heredity 51: 501-506.

White M.J.D. 1973: Animal Cytology and Evolution. 3rd ed. Cambridge University Press, Cambridge, $961 \mathrm{pp}$.

White M.J.D. 1978: Modes of Speciation. W.H. Freeman, San Francisco, $455 \mathrm{pp}$.

Received December 16, 2003; revised August 9, 2004; accepted September 7, 2004 